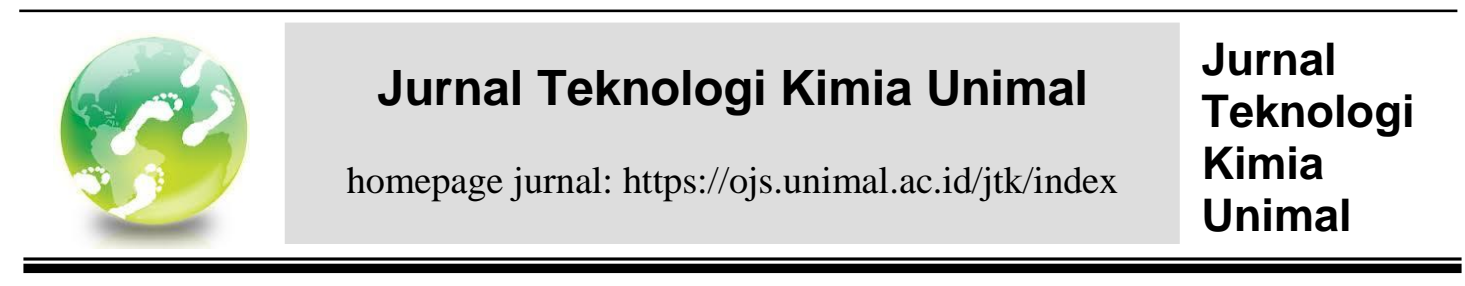

\title{
Pembuatan Biofoam Dari Ampas Tebu Dan Tepung Maizena Syamsul Bahri ${ }^{1)}$, Fitriani ${ }^{1)}$, Jalaluddin ${ }^{1)}$. \\ ${ }^{1}$ Jurusan Teknik Kimia, Fakultas Teknik, Universitas Malikussaleh \\ Kampus Utama Cot Teungku Nie Reuleut, Muara Batu, Aceh Utara - 24355 \\ Korespondensi:HP: 085260055045, e-mail: fitrialsm170@gmail.com
}

\begin{abstract}
Abstrak
Penggunaan stryrofoam sebagai kemasan makanan secara terus-menerus berdampak buruk bagi kesehatan manusia dan lingkungan, untuk mengatasi dampak tersebut diperlukan kemasan makanan yang dapat didaur ulang dan ramah lingkungan sebagai pengganti stryrofoam. Biofoam merupakan kemasan alternatif pengganti styrofoam yang terbuat dari bahan baku alami, yaitu pati dengan tambahan serat untuk memperkuat strukturnya. Ampas tebu dan tepung maizena merupakan sebagai bahan dasar dalam pembuatan biodegradable foam dan Penambahan magnesium strearat bertujuan untuk meningkatkan kuat tarik dan daya serap air, penetelitian ini bertujauan untuk pengaruh konsentrasi $\mathrm{NaOH}$ terbaik dan untuk mengatahui tingkat biodegrabeliti yang terlalu tinggi, dengan variasi konsentrasi ampas tebu $50 \mathrm{gr}, 55 \mathrm{gr}$ dan $60 \mathrm{gr}$ dengan konsentrasi $\mathrm{NaOH}$ (0 \%, 2,5\%, 5\% dan 7,5\%). Pada penelitian ini diperoleh hasil karakteristik terbaik untuk uji ketahanan kua tarik pada variasi 0\% dengan ampas tebu $50 \mathrm{gr}$ didapatkan dengan nilai $0,60 \mathrm{kgf} / \mathrm{mm}^{2}$ ), sedangkan uji kadar air didapatkan nilai terbaik pada konsentarasi $0 \%$ dengan amaps tebu 50 gr didapatkan dengan nilai $4,4 \%$
\end{abstract}

Kata kunci: styrofoam, biofoam, konsentrasi NaOH, ampas tebu dan biodegrabel

\section{PENDAHULUAN}

Gaya hidup manusia yang kian praktis dan semakin berkembangnya inovasi dalam pembuatan suatu produk sehingga meningkatnya konsumsi plastik dalam berbagai sisi kehidupan. Akibatnya ketergantungan manusia terhadap kemasan plastik dalam kehidupan sehari-hari sangat tinggi. Saat ini produksi plastik dunia diperkirakan mencapai 100 juta ton setiap tahunnya (Anonymous, 2010). Satu jenis plastik yang digunakan adalah styrofoam. Styrofoam adalah salah satu produk yang digunakan sebagai kemasan makanan dalam kehidupan sehari-hari cukup tinggi. Hal ini terjadi dikarenakan karakteristik dari styrofoam yang mudah dibentuk, ringan, murah, tahan air, dan juga tahan panas Kandungan 
dalam styrofoam untuk kemasan makanan memiliki efek buruk bagi kesehatan manusia, hal ini disebabkan bahan kimia yang terkandung di dalam styrofoam masuk ke makanan yang dikonsumsi manusia. Mengingat besarnya dampak buruk yang ditimbulkan oleh penggunaan Styrofoam, maka para ahli berupaya mencari alternatif bahan pengemas lain yang lebih ramah lingkungan. dimanfaatkan sebagai bahan baku pembuatan biofoam atau biodegradable foam adalah produk pertanian yang persediaannya melimpah dan bahan baku yang digunakan seperti mengandung pati dan selulosa. Sehingga dapat diperbaharui dan harganya juga lebih murah. Biofoam dapat terurai secara alami (biodegradable) dan juga dapat diperbarui(renewable).Biofoam yang terbuat dari polimer alami (pati dan serat), umumnya memiliki sifat mekanis yang rendah.

Hasil penelitian (Evi, 2015) menunjukkan bahwa pemilihan tepung tapioka memiliki kadar pati lebih tinggi dibandingkan ampok tetapi ampok memilki kadar lemak, protein dan serat yang lebih besar dibandingkan tapioca. Perbedaan komposisi ini berpengaruh terhadap karakteristik biofoam yang dihasilkan. Berdasarkan latar belakang diatas, peneliti ingin mencoba memanfaatkan ampas tebu dan tepung maizena merupakan hasil pertanian yang dibuang ke lingkungan dan mudah didapatkan tanpa diolah lebih lanjut. Ampas tebu memiliki kandungan selulosa sekitar 37,65\% (Sudarmito,2015) dan tepung maizena memiliki kandungan pati sekitar 54,1\%- 72\% (Singh et al, 2008). Dengan demikian untuk mencengah penggunaan styrofoam dengan pengganti biofoam adalah salah satu pilihan alternatif dan diharapkan dapat digunakan untuk mengemas produk segar maupun produk olahan dengan kadar air sedang seperti buah-buahan utuh, sayuran atau produk pangan siap saji seperti ayam goreng dan kue-kue.

\section{Tinjauan Pustaka}

\subsection{Ampas Tebu}

Industri gula dapat menghasilkan ampas tebu sekitar $32 \%$ dari berat tebu giling. Ampas tebu, atau disebut juga dengan bagas, adalah hasil samping dari proses ekstraksi cairan tebu. Ampas tebu sebagian besar mengandung lignocellulose. Panjang seratnya antara 1,7-2 mm dengan diameter sekitar $20 \mu \mathrm{m}$, 
sehingga ampas tebu ini dapat memenuhi persyaratan untuk diolah menjadi papan-papan buatan. Serat bagas tidak dapat larut dalam air dan sebagian besar terdiri dari selulosa, pentosan dan lignin. Hasil analisis serat bagas tercantum dalam Tabel 1 (Sudaryanto dkk.,2002).

Tabel 1. Komposisi kimia ampas tebu

\begin{tabular}{|l|c|}
\hline Komposisi kadar & Kadar \% \\
\hline Abu & 3 \\
\hline Lignin & 22 \\
\hline Selulosa & 37 \\
\hline Sari & 27 \\
\hline Pentosan & 3 \\
\hline SiO2 & \\
\hline
\end{tabular}

Ampas tebu memiliki fisik yaitu bewarna kekuning-kuningan, berserat (berserabut), lunak dan relatif membutuhkan tempat yang lunak untuk penyimpanan dalam bentuk arang dengan jumlah yang sama (Rosmawar, 2014). Ampas tebu merupakan senyawa komplek lignoselulosa. Selulosa merupakan bagian utama susunan jaringan tanaman berkayu, bahan tersebut terdapat juga pada tumbuhan perdu seperti paku, lumut, ganggang dan jamur.

Penambahan protein dan serat tersebut untuk memperbaiki sifat fisik dan mekanis biofoam yang dihasilkan. Peningkatan konsentrasi serat dapat meningkatkan sifat mekanis produk serta mengurangi kadar air produk setelah di proses pencetakan. Peningkatan konsentrasi protein dapat mengurangi kadar air setelah pencetakan, kapasitas penyerapan air serta laju kerusakan. Hasil terbaik dari penelitian ini adalah dengan menggunakan campuran serat $20 \%$ dan protein $10 \%$.

\subsection{Tepung Maizena}

Jagung (Zea mays L) merupakan salah satu tanaman serealia dari keluarga rumput-rumputan (Graminae). Jagung diklasifikasikan kedalam divisi Agiospermae, kelas monocotyledoneae, Ordo poales, Famili poaceae, dan Genus 
Zea. Menurut SNI 01-3727-1995, tepung jagung adalah tepung yang diperoleh dengan cara menggiling biji jagung yang bersih dan baik (Suarni, 2008)

Tabel 2 komposisi kimia tepung maizena dipasaran

\begin{tabular}{|c|c|}
\hline Parameter & Jumlah (\%) \\
\hline Kadar air & $12,60 \%$ \\
\hline Kadar abu & $0,30 \%$ \\
\hline Kadar protein & $0,54 \%$ \\
\hline Kadar lemak & $0,77 \%$ \\
\hline Kadar karbohidrat & $85,79 \%$ \\
\hline
\end{tabular}

Jagung terdiri dari beberapa jenis, tergantung pada komposisi bahan penyusunnya. Jagung dengan soft endosperm umumnya digunakan dalam proses wet milling untuk menghasilkan pati jagung yang dapat digunakan sebagai bahan baku pembuatan pemanis, produk pangan, dan bioetanol. Jagung dengan hard endosperm umumnya digunakan dalam proses dry milling dimana dihasilkan bahan baku untuk pembuatan produk ekstrusi dan pakan (Rooney dan Suhendro, 2001).

Proses pembuatan tepung jagung biasanya dilakukan dengan cara penggilingan kering (dry milling) (Yuan dan Flores, 1996). Adapun keunggulan dari penggunaan tepung jagung diantaranya adalah dapat mengurangi biaya bahan baku dan produksi, tidak menggunakan pewarna sintetis untuk member warna kuning yang diinginkan karena adanya kandungan beta karoten, dan dapat mengurangi ketergantungan terhadap penggunaan bahan baku tepung terigu. Komponen terbesar dalam tepung jagung adalah pati. Berdasarkan penelitian Juniawati (2003), tepung jagung memiliki kadar pati sebesar 68,2\%.

Pati merupakan bagian terbesar dari tepung, dapat digunakan sebagai bahan pengikat dan bahan pengental, industri pangan banyak menggunakan tepung tapioka dan tepung sagu tersebut sebagai bahan pengikat. Penggunaan tepung tapioka dan tepung sagu tersebut sebagai bahan pengikat disebabkan harganya yang relatif murah, memberikan daya ikat yang tinggi dan membentuk tekstur yang kuat 


\subsection{Biofoam}

Inovasi teknologi biofoam yang menghasilkan produk bahan kemasan ramah lingkungan dan aman bagi kesehatan menjadi solusi cerdas mengatasi membanjirnya kemasan plastik dan Styrofoam. Kelebihan dari biofoam, dapat terurai secara alamiah (biodegradable) sehingga tidak berdampak buruk pada lingkungan.

Biofoam merupakan kemasan alternatif pengganti styrofoam yang terbuat dari bahan baku alami, yaitu pati dengan tambahan serat untuk memperkuat strukturnya. Dengan demikian produk ini tidak hanya bersifat biodegradable, tetapi juga renewable.

\section{Bahan dan Metode}

Penelitian ini dilaksanakan dilaboratorium Teknik Kimia Universitas Malikussaleh. Bahan dan peralatan yang diperlukan dalam penelitian ini antara lain adalah Blender, 80 Mesh, Hot plate, Beaker glass, Oven, Pengaduk, $p H$ dan Cetakan. Air (Aquades), NaOH, Magnesium Steaterat, Tepung maizena dan Ampas tebu 80 Mesh.

Untuk mendapatkan hasil penelitian yang diinginkan dan analisnya, digunakan variable-variabel sebagaimana dibawah ini. Variabel Tetap Aquades 90 ml,Waktu pemanasan $85{ }^{\circ} \mathrm{C}$ selama 30 menit, Magnesium strearat $1 \mathrm{gr}$,Perbandingan waktu (3,6,9,12 dan 15 hari), Perbandingan tepung maizena dan amaps tebu 50 gr (1:5), Perbandingan tepung maizena dan amaps tebu 55 gr (2:5), Perbandingan tepung maizena dan amaps tebu 60 gr (3:5). Variabel Bebas, Konsentrasi $\mathrm{NaOH}(0 \%$, 2,5\%, 5\% dan 7,5\%), Ampas tebu (50 gram, 55 gram dan 60 gram). Variabel Terikat, Kuat tarikKadar air

Ampas tebu kering dihaluskan menggunakan blender dan diayak lolos 80 mesh. Serbuk ampas tebu ditimbang sebanyak $50 \mathrm{~g}$ dan ditambahkan $50 \mathrm{ml}$ aquades yang dilarutan dengan $\mathrm{NaOH}$ sesuai variasi. Kemudian dipanaskan dengan mengunakan hot plate pada suhu $85^{\circ} \mathrm{C}$ selama 30 menit. Selanjutnya disaring dan dicuci dengan air sampai $\mathrm{pH}$ netral serta dikeringkan dengan oven pada suhu $105^{\circ} \mathrm{C}$ selama 1 jam. 
Bahan baku berupa serat ampas tebu (sesuai variasi) dicampurkan dengan pati yang berasal dari tepung maizena dengan perbandingan (1:5) dari massa total bahan baku kering dan air sebanyak $90 \mathrm{ml}$. Selanjutnya ditambahkan dengan magnesium stearat sebanyak $1 \mathrm{~g}$ kemudian diaduk dengan mixer sampai adonan menjadi homogen. Kemudian masukan adonan ke dalam cetakan biofoam dengan suhu $170^{\circ} \mathrm{C}$ selama 30 menit dengan pemberat sebesar $4 \mathrm{~kg}$.

\section{Hasil dan Diskusi}

Ketahanan tarik kertas menunjukkan kemampuan kertas dalam mempertahankan keadaannya agar tidak putus jika dikenai renggangan. Kuat tarik merupakan gaya tarik maksimum yang dapat ditahan sampai putus, kuat tarik yang terlalu kecil tidak dapat dijadikan kemasan karena karektrer fisiknya kurang kuat dan mudah patah. Hubungan waktu pemasakan dan kuat tarik pada grafik 4.1 dibawah ini.

Gambar 4.1 Hubungan Komposisi bahan baku dengan nilai kuat Tarik

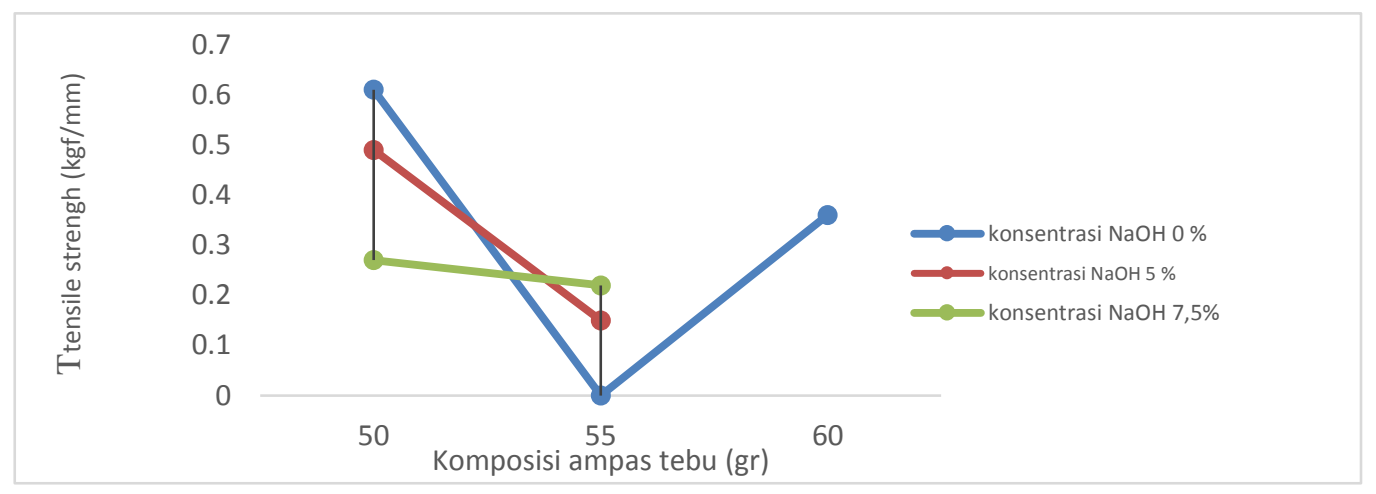

Gambar 4.4 Hubungan Komposisi bahan baku dengan nilai kuat Tarik

Menunjukkan bahwa nilai ketahanan tarik yang paling tinggi pada bahan baku 50 gr dan konsentrasi $0 \%$ yaitu: $0,61 \mathrm{Kg} / \mathrm{mm}^{2}$ dan ketahanan tarik paling rendah pada bahan baku ampas tebu 55 gr, konsentrasi $5 \%$ yaitu: $0,15 \mathrm{Kg} / \mathrm{mm}^{2}$. Terdapat perbedaan disetiap perlakuan konsentrasi larutan $\mathrm{NaOH}$ dan Komposisi bahan baku ampas tebu. Uji ketahanan tarik tertinggi pada komposisi bahan baku, konsentrasi $0 \%$ dengan hasil $0,61 \mathrm{Kg} / \mathrm{mm}^{2}$. Hal tersebut terjadi disebabkan karena serat-serat pada selulosa terurai dan membentuk serat panjang. Kandungan selulosa yang tinggi sehingga serat selulosa mampu berkaitan satu sama lain. 
Menurut Monica (2009), bahwa faktor yang mempengaruhi ketahanan tarik adalah kekuatan individu serat yang lemah, panjang serat, kemampuan pengikatan serat tergantung pada proses penekanan atau pengepressan dan struktur permukaan biofoam.

Ketahanan tarik terendah pada komposisi bahan baku 55 gr, konsentrasi $5 \%$ dengan hasil $0,15 \mathrm{Kgf} / \mathrm{mm}^{2}$. Hal tersebut terjadi dikarenakan komposisi bahan baku yang menyebabkan serat selulosa tidak terurai dan menyebabkan serat terputus, ketebalan biofoam atau adonan tidak tercampur dengan secara hemogen atau rusak sehingga serat tidak dapat memberikan satu sama lain membentuk lembaran biofoam yang kuat,

Siti Norachmi (2017) menyatakan bahwa ketebalan mempengaruhi kekuatan tekan, plastik yang tipis menyebabkan kuat tekan yang dapat ditrima hanya sedikit. Hal ini disebabkan kerena ikatan bahan-bahan yang terkandung dalam satu plastik yang tebal akan lebih menguatkan ikatan.

begitu pula sebaliknya dikarenakan Perbedaan ketahanan tarik juga dapat disebabkan tidak ratanya biofoam pada saat pencetakan, karena dilakukan secara manual dan juga disebabkan karena peingkatan jumlah serat daun ampas tebu yang lebih tinggi menyebabkan kadar selulosa yang terlalu tinggi sehingga kurang bisa menyerap air. Akibatnya air tidak dalam keadaan terikat sehingga adonan biofoam menjadi encer. Encernya adonan biofoam mengakibatkan biofoam yang dihasilkan menjadi rapuh saat dipanaskan sehingga kuat tarik biofoam menurun.

\section{2 kadar air}

Pengujian kadar air dilakukan untuk mengetahui ketahanan biofoam terhadap penyerapan air. Pada penelitian yang dilakukan untuk mendapatkan data persentase kadar air biofoam pada berbagai variasi waktu dan suhu proses. Biofoam berbasis pati sangat rentan terhadap air karena adanya ikatan hidrogen pati, sehingga dapat melemahkan dan menurunkan sifat fungsional dari foam, penelitian ini dilakukan dengan cara menghitung perubahan berat akibat banyaknya air yang diserap biofoam setelah diovenkan selama 24 jam.

Kadar air pada adonan biofoam berfungsi sebagai blowing agent untuk meningkatkan ekspansi adonan sehingga menghasilkan struktur berongga. 
Adonan yang terlalu encer akan menyebabkan ekspansi yang berlebihan sehingga struktur biofoam yang dihasilkan memiliki banyak rongga, dinding yang tipis dan daya serap air yang tinggi.

Berikut ini Gambar 4.5 Hubungan kadar air (\%) Terhadap Bahan Baku Biofoam dari bahan baku ampas tebu 50 gr, 55 gr dan 60 gr

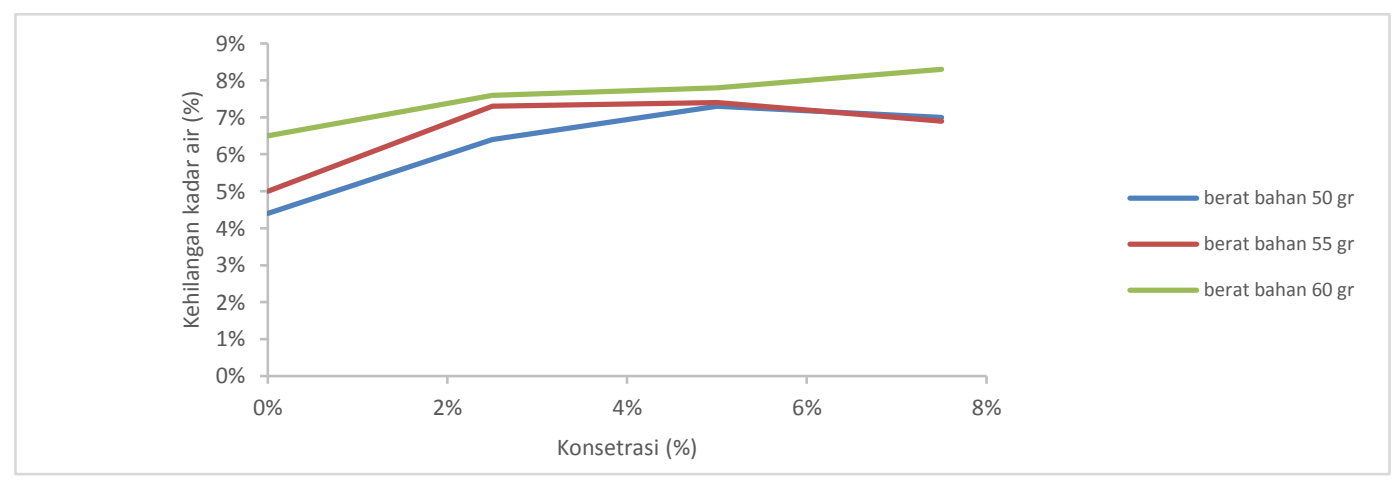

Gambar 4.5 grafik hubungan konsetrasi (\%) terhadap persen kadar air pada berat bahan baku 50 gr, 55 gr dan 60 gr.

Berdasarkan pada gambar grafik diatas, dapat terlihat bahwa hubungan antara konsentrasi $\mathrm{NaOH}$ dengan berat bahan baku 50 gr, 55 gr dan 60 gr ampas tebu. Kadar air biofoam pada penelitian ini berkisar antara 4,4-8,3\%, menunjukkan bahwa Kadar air yang tinggi diperoleh pada bahan baku ampas tebu 60 gr dengan konsentrasi 7,5\% yaitu: 8,3\% kadar air yang tinggi menyebab semakin encernya adonan ketikan semalin banyak yang ditambah, adonana yang terlalu encer akan menyebabkan ekspansi yang belebihan sehingga struktur biofoam yang dihasilkan strukruk biofoam yang dihasilkan memiliki banyak rongga, dinding yang tipis dan daya sera air yang tinggi

Pada bahan baku ampas tebu 50 gr dengan konsentrasi $0 \%$ yaitu: $4 \%$. Terjadinya kenaikan dan penurunanya Kadar air disebabkan karena biofoam yang berbasis pati umumnya adalah bahan alami yang bersifat higroskopis dan dapat menyerap kelembaban dari lingkungan (Glenn and Hsu 1997; Soykeabkaew et al., 2004). Hal ini yang menyebabkan nilai kadar air biofoam jauh lebih tinggi dari kadar air styrofoam $(1,11 \%)$ nilai kadar air pada biofoam juga dipengaruhi oleh penambahan polimer sintetik, protein dan serat. Hal ini kemungkinan besar 
disebabkan karena magnesium streatrea bersifat lebih hidrofobik dibandingkan pati.

\section{Daftar Pustaka}

1. Anonymous. 2010. Bioplastic at a glance.www.european-bioplastics.org. Akses tanggal 18 September 2018.

2. Evi Savitri Iriani. 2015. Pengembangan Produk Biodegradable Foam Berbahanbaku Campuran Tapioka dan Ampok. Bogor

3. Glenn GM, Hsu J. 1997. Compression-formed starch-based plastic. Ind Crops Prod.7:37-44

4. Juniawati. 2003. Optimasi Proses Pengolahan Mi Jagung Instan Berdasarkan Kajian Preferensi Konsumen. Skripsi. Departemen Ilmu dan Teknologi Pangan. Fakultas Teknologi Pertanian. IPB. Bogor.

5. Rosmawar "arang aktif ampas tebu sebagai adsorben pada pemurnian minyak goreng bekas

6. Singh S et al. 2008. Effect of incoporating sweet potato flour to wheat flour on the quality characteristics of cookies. African Journal of Food Science.

7. Suarni, M. Aqil, and I.U. Firmansyah. 2008. Starch characterization of several maize varieties for industrial use in Indonesia. Proceeding of The 10th Asian. Regional Maize Workshop. p.74-78.

8. Sudaryanto, Y., Antaresti, Wibowo. H. 2002. Biopulping Ampas Tebu Menggunakan Trichoderma viride dan Fusarium solani. hal. 163171.Prosiding Seminar Nasional Fundamental dan Aplikasi Teknik Kimia: Surabaya

9. Sudarminto.2015.Tanaman Tebu (Saccarum officinaru) Http://darsatop.lecture.ub.ac.id/2015/10/tanaman-tebu-saccarumofficinaru/ (diakses pada tanggal 20 September 2018

10. Surya Indah. (1996). Pengaruh Konsentrasi NaOH dan Waktu Penguapan pada

11. Proses Kostisasi terhadap Kualitas Kain Rayon Viskosa. Skripsi: UII Yogyakarta

12. Zou GX, Jin PQ, Xin LZ. 2007. Extruded starch/PVA composites:Water resistance, thermal properties and morphology. J Elast Plast. 40:303-316. 